\title{
水文レジムによる河川流域区分
}

\section{Classification of catchments by hydrologic regimes}

\author{
葛葉泰久* \\ Yasuhisa KUZUHA \\ 友杉邦雄 ${ }^{* *}$
}

Kunio TOMOSUGI

岸井徳雄 ${ }^{*}$ ・早野美智子*

Tokuo KISHII · Michiko HAYANO
(防災科学技術研究所)

National Research Institute for Earth Science and Disaster Prevention

(京都大学防災研究所)

Disaster Prevention Research Institute, Kyoto University

（防災科学技術研究所）

National Research Institute for Earth Science and Disaster Prevention

\begin{abstract}
Classifying river basins by a hydrologic regime that is valuable information for analysis of flood and drought was carried out. Japanese river basins were classified to six hydrologic regimes by general survey of annual change of monthly discharge. Then, relationships between mean annual floods (MAF) per area and catchment area, and between the coefficient of variation (CV) of maximum annual floods and catchment area were analysed, and validity of the classification and the possibility of this kind of analysis, that is rainfalt-runoff analysis by MAF, CV, and catchment area, were examined. As a result, the classification was verified, but it was suggested that more accurate analysis is undertaken by using additional information, for example regions to which catchments belong, as well as regimes.
\end{abstract}

Key Words : Hydrologic regime, Runoff, Catchment, Annual maximum floods, Coefficient of variation

洪水, 渴水, 双方に関する研究を行う際に必要な, 河川流域のクラス分けを試みた. 流量年表を用い, 月流量の年内変化を調べ て，全国の流域を大きく分けて6つのレジムにクラス分けした，次に，年最大流量の平均値，変動係数と流域面積との関係による 解析を行い, クラス分けの妥当性を検証するとともに,レジム分けをともなった年最大流量と流域面積の関係を介した降雨一流出 過程に関する研究の可能性の検討を行った. その結果, レジム分けは妥当であるが, 河川流域の属する地方, その他の情報を同時 に用いた方がより正確な解析が行えることが示峻された。

キーワード: 水文レジム, 流出, 流域, 年最大流量, 変動係数

\section{I . 序 論}

地球全体から見るとその占める面積が決して大き いとは镸えない我が国国土ではあるが，南北・東西 に弧状に伸びたその形状，国土のかなりの部分を占 める山地の影響, 暖流・寒流の影響, 季節風の影響 等により，我が国は様々な気侯区分に分割される (図一1)。それらの気候特性，また地形学的特性 等が水文素過程に大きく影響するので,「降雨一流 出特性」の検討を行う際に, 河川流域をその気候特
性・地形学的特性等を反映した水文学的特性により, いくつかのレジムにクラス分けすることが有効とな る場合がある.

岩佐(1979)には,

1）河川の特性を流量の関数として表すことをレジ ム説という。

2) 元々河川のもつすべての物理現象の記述である と定義されるが, 現在は狭義に解釈されることが 多い.

とあるが，本論文では「レジム」の意味を広義に解

\footnotetext{
*防災科学技術研究所 テ305-0006 つくば市天王台3-1

National Research Institute for Earth Science and Disaster Prevention, 3-1, tsukuba, 305-0006, Japan

**京都大学防災研究所 $\mathbf{T} 611-0011$ 宇治市五ヶ生

Disaster Prevention Research Institute, Kyoto University, Gokasho, Uji, 611-0011, Japan
} 


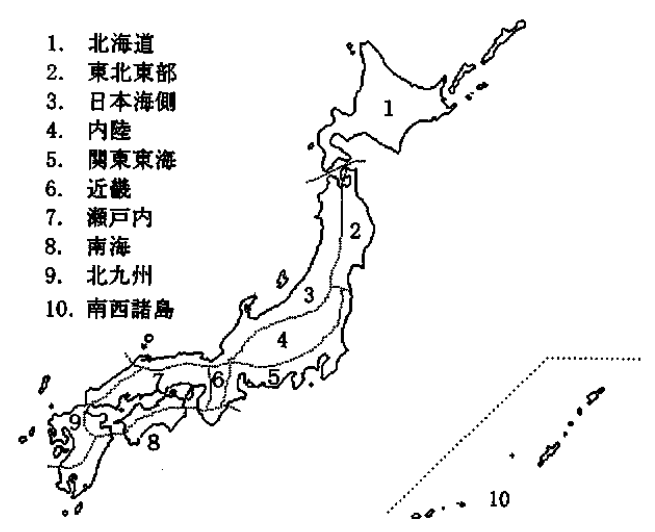

図-1 日本の気候区分 (渡辺(1973) 等を参考に作成) Fgi. 1 Japanese climatic classification

釈する，ただし，各河川流域での流出特性が，「す べての物理現象を反映した結果」であると考え，特 に流量の年内変動に着目し, 日本国内の流域をいく つかのレジムにクラス分けする，なお，本来，「河 川」を分類するのであるが，「河川の特徴」を，「そ れを含む流域の特徵」と考えて，本論文では， Kresser(1981)に関する記述以外，「河川流域」とい う用語を用いる。

本論文で，河川流域のレジム分類をしょうとした 動機は，1）洪水災害を対象とした，降雨一流出過 程の理解に必要である，2）渴水災害を対象とした， 少雨の分布特性の検討に必要である，の二つである が,ここでそれらに関して概説する.

近年, 流出現象における「スケール問題」の一つ として，流域における年最大流量の平均值と流城面 積の関係や年最大流量の変動係数と流域面積の関係 を介した流出現象のスケール問題的アプローチによ る研究がいくつか行われている(例えば, Smith, 1992 ; Gupta and Dawdy, 1995 ; Blöschl and Sivapalan, 1997 : Robinson and Sivapalan, 1997). 特に「年最大 流量の変動係数-流域面積関係」において，その関 係の根拠について色々な解䣋がなされている. 例え はSSmith(1992)は,「変動係数一流域面積」関係(後 に示す図ー9と類似の図，ただし対象としているのは米 国, central Appalachian region)について，「ある流域 面積以下では変動係数が増加する傾向にあり，それ 以上では減少する」ことを示し，その解釈を二つの 仮説で説明している.一方, Blöschl and Sivapalan (1997)は, Austriaの河川流域を対象に解析を行い, 「一見複雑なそれらの関係は, 河川(流域)をいくつ
かのレジムに分類して考え，それぞれのレジムによ る「変動係数一流域面積関係」の集合と考えるとわ かりやすい」と結論づけている。この解析において, Kresser(1981)による水文レジムの概念が使用され ている. 著者らもEagleson $(1971 ， 1972)$ の古典的モ デル利用し，それらの関係をもとに，降雨一流出関 係の理解をすることを目的とした解析的研究を行っ ているが, Blöschl and Sivapalan(1997) と同様, 実 流域デー夕をもとにした解析も必要と考えている. そのため, それにさきがけ, 河川流域のレジム分類 をすることが必要と考えた.これが上述の動機 1) にあたる。

また，著者らは渴水災害に関する研究として，少 雨の空間分布特性に関する考察(葛葉ら，2001)を行 う. そこでは平均年降水量の分布特性とともに,

「降水量」の変動係数による解析が行われているが, 「降水量」として「年降水量」だけでなく，「夏期 の降水量」,「8～10月降水量」等, 対象とする地域 における，「大きな流量の原因となる降水量」が用 いられる. その際, 対象としている地域で,「どの 季節の流量が卓越しているか」という情報が必要と なることは言うまでもない.これが, 動機 2 ) にあ たる。

上述のように, 河川流域をいくつかのレジムに分 けて「降雨一流出関係」を論ずることは，洪水災害， 渴水災害双方にとって，その解析をする上で一つの 有益な手段となりうる。このように，洪水災害・災 害の両方を視野に入れて, 降水量, 地形等の自然要 因を反映した地域の類別化を行おうとした類似の研 究として, 角屋らによる報告(日本農業総合研究所, 1984)があげられる.また，日本の河川の個別的特 徵を詳細に調べ，また，地質構造を同じくする地域 ごとの地域性についても言及した研究として、小出 (1970，1972)があげられる. 他にも，数々の河川類 別化に関する研究はあるが, 本論文では, 上述の動 機 1）2）により，その目的に合致した分類を試み るものである.

なお，年最大流量一流域面積の解析において， Blöschl and Sivapalan(1997), 葛葉ら(2000), また 本論文においても，実際は「年最大流量／流域面積」 (次元は比流量)を用いており, 洪水比流量に関する 研究についてはCreager(1944)など，また我が国に おいても石原・佐藤 (1975), 角屋・永井 (1979), 日 本農業総合研究所 (1984) など, 多くの成果がある. また，それらを「地域別」に評価したものとしては， 
上記の角屋・永井 (1979) 以外にも, 建設省土木研究 所(1976)などがある. 本論文でも, 後に, 各レジム における，「年最大流量の変動係数一流域面積」と ともに,「平均年最大流量一流域面積」の形状に関 して言及しているが，その目的は，(既往最大洪水, 可能最大洪水の)包絡線を求める/近似式を求める等 ではなく、レジムの分割の妥当性を検証することで ある.すなわち、レジムにより分割することにより， 非常に複雑な形状を示すそれらの関係(図一9)が,

(近似式を定義できるほど) 明確な関係を持つように なったかどうかを検証することである.

\section{II. 手法と資料}

レジム分類，また後述する年最大流量を用いた検 討の双方で, 流量年表(建設省河川局編)を用いた. まず，レジム分類について述べる．流量年表を用い， 昭和50年からの 10 年分のデー夕を平均し，まず12ヶ 月分の平均月流量を求めた．ただし，データの信頼 性の有無により，また流量観測点の変化により，必 ずしもすべての点で同一年のデータを用いたとは限 らない. 正確には「昭和50年〜昭和62年のデータの うち, 可能な限り10年分のデータを用いた. 流域に よっては10年末満のデータを用いた場合もある」で ある、最新のデータを用いなかった理由は以下のと おりである.すなわち, 後述する「年最大流量を用 いた解析」では流量を「自然河川での流量」である と仮定し，またそれらを含む河川の様相の変化を考 虑していない. Eagleson(1971，1972)をはじめとす る,この種の, 年最大流量を用いた既往の研究でも それは同様である。しかし実際には河川の様相は次 第に変わってきていることが考えられる.そこで, 月流量 (の平均値)を求めるにあたり，「年最大流量 を用いた解析」において用いたデータの，(時間的 に)ほほ中心に位置する昭和50年代のデー夕を用い た. それぞれの流域において，まず月流量の平均値 を求め, その12ヶ月の変化の様相を見た.

Kresser(1981)はAustriaの河川を以下のようにク ラス分けしている.すなわち,

(1)Glacier dominated streams

(2)Snow and glacier dominated streams

(3) Snow dominated mountain streams

(4) Streams from prealpine foothills and hilly terrain

(5)Groundwater dominated lowland streams

(6) Large rivers
である，我が国の場合，流域によって，冬季の降雪， 梅雨等の雨期, 台風等が流域の性質を決定している と思われる，そこでそれらの影響について，月流量 の年内変化を見ながら検討し，クラス分けを行った。

次に「年最大流量を用いた解析」について述べる。 これも流量年表を用いた，各流域について，流量年 表に記載されている毎年の年最大流量を用い, その 平均值を流域面積 (Area)で割った值(Specific Mean Annual Flood; SMAF), 変動係数(CV)を計算した. そして「CV-Area関係」、「SMAF-Area関係」を求 めた. ここで用いたデータは，昭和38年〜平成 8 年 のものである．ただし，20年分以上のデータがある 流域のみを解析対象流域とした。

なお,これ以降, 流量観測点名によって流域を表 し，水系名，河川名を併記することにする.

\section{III.レジムクラス分け}

IIで述べたような手法で河川流域の区分を行った。 その結果，大きく分けて 6 種類のレジム(表ー1)に 分割することができた，以下，それぞれについて述 ベる.

\section{1.レジムH}

北海道内流域の流量の月変化はほほ全域にわたっ て類似の特徵を示す. 図一 2 は石狩大橋(石狩川水 系石狩川ににおける平均月流量の年内変化を表した 図である，ただし，図の縦軸はそれらの年合計值に 对する割合(パーセント表示)である。このように， 北海道内の流域のほとんどは(後述する 3 つの流域を 除く流域で)春期に年最大月流量を示す。これは， 冬季の降雪の融雪流出が多いことを示している.こ のように春期に流量が多い流域は，東北地方日本海 側, 北陸地方をはじめ, 他の地域にも存在するが, 北海道の多くの流域で春期の流量の年流量に対する 割合が他の地方の流域と比べてかなり大きいこと， また気候区分を考虑して，北海道内で春期の融雪流 出が卓越している流域のみをレジム $\mathrm{H}$ に属すとした. ただし，レジムHには，3，4，5月の3ヶ月流量 が年内の 3 ヶ月流量の最大値をとるものと， 4,5 , 6 月のものが最大值をとるものがある，なお，西越 (石狩川水系千歳川), 弟子屈(釧路川水系銀路川)では 図一3のように春期の流量がそれほど目立ったもの になって㧍らず, 音更(十勝川水系音更川)では夏期 〜秋期の流量が春期より多くなる. 
表ー1 河川(流域)のレジム分類(河川名, 観測点名が年によって異なる場合は, 原則として平成 8 年版流量年表に 従った)

Table 1 Regime classification for Japanese catchments. Catchments are classified into six regimes.

\begin{tabular}{|c|c|}
\hline$H$ & 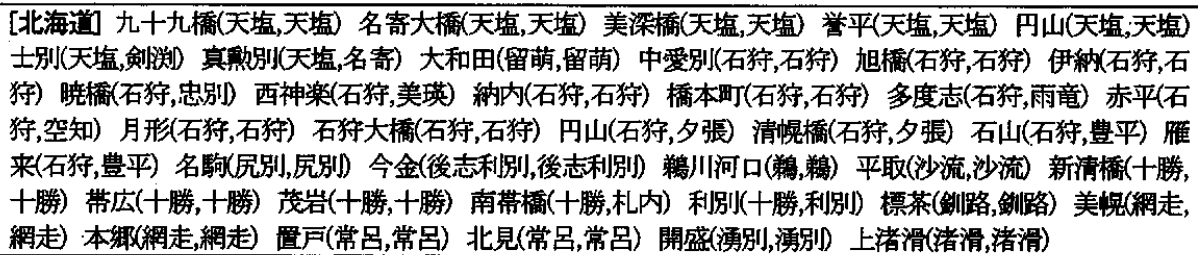 \\
\hline & 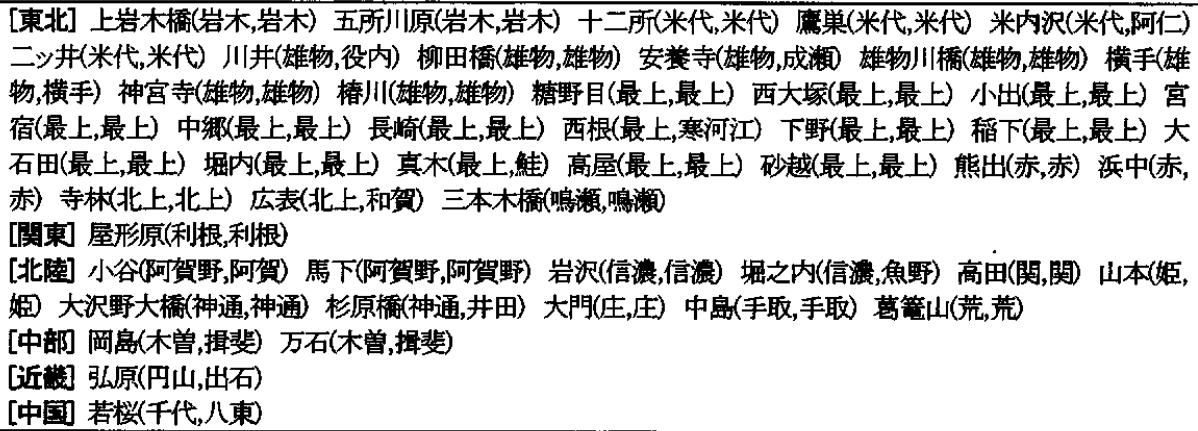 \\
\hline & 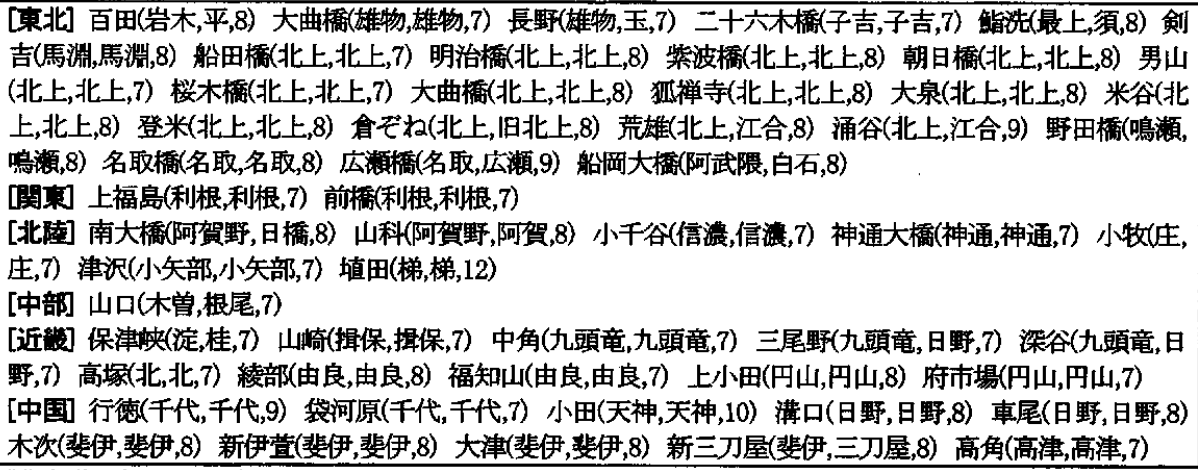 \\
\hline S & 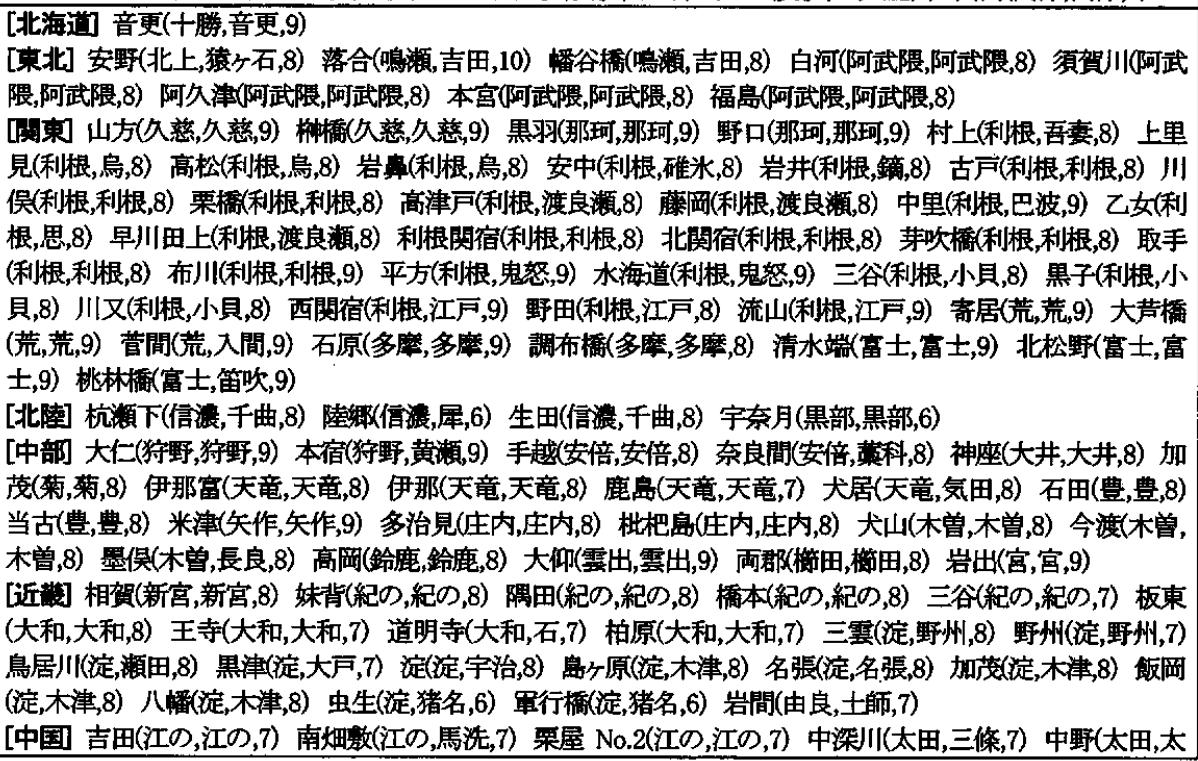 \\
\hline
\end{tabular}




\begin{tabular}{|c|c|}
\hline & 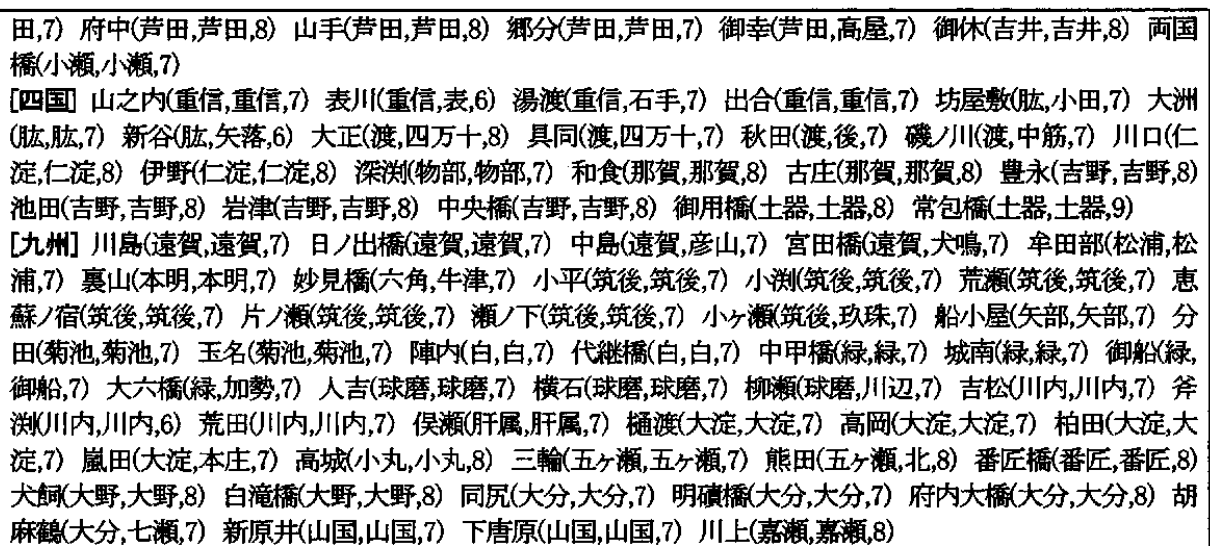 \\
\hline SW & 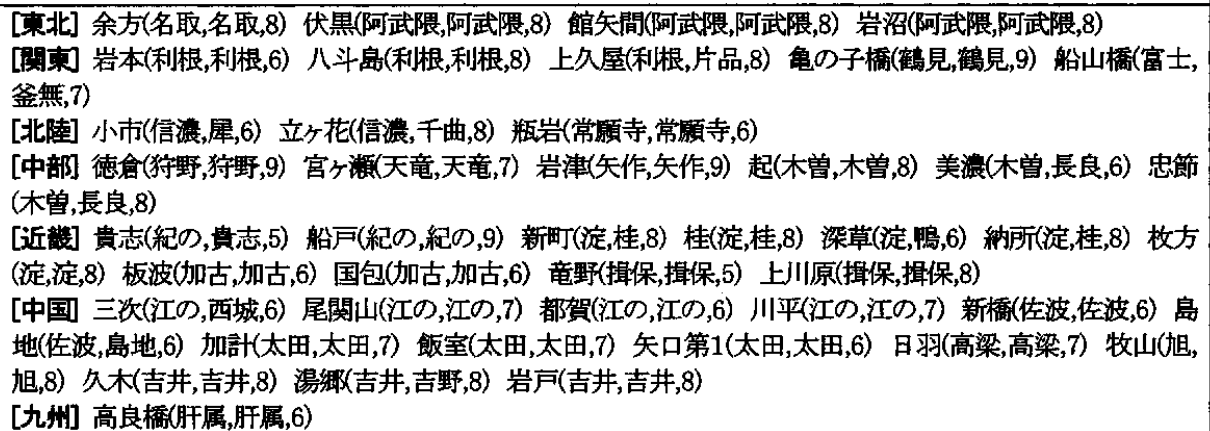 \\
\hline $\mathrm{C}$ & 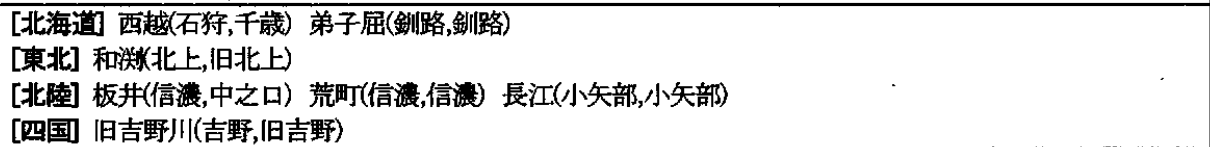 \\
\hline
\end{tabular}

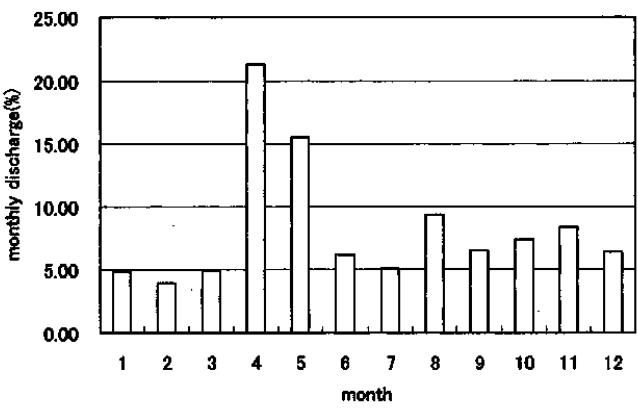

図一2 平均月流量の年内变化 (レジム H)

Fig. 2 Monthly variability of discharge (Regime $\mathrm{H})$. Graph shows mean monthly flows as percentage of annual flow.

\section{2.レジムTN}

東北地方の日本海側では，冬季に降水量が多い. 東北地方東部では冬に雪が少なく, 西部では夏冬二 つの降水の極大があると言われている。ここでは東 部，西部にかかわらず， $3 ， 4 ， 5$ 月または 4,5 ，

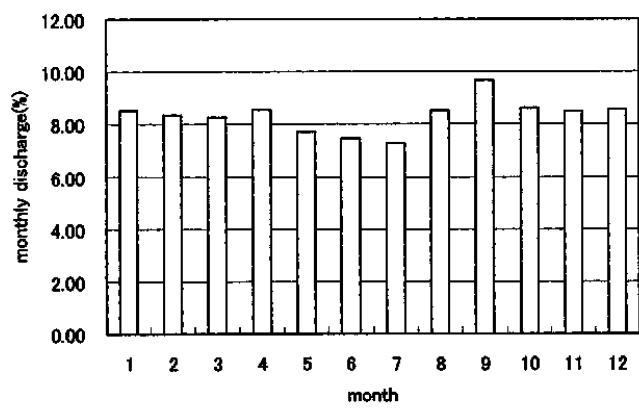

図一 3 平均月流量の年内変化 (レジムC)

Fig. 3 Monthly variability of discharge (Regime C)

6 月の 3 ケ月流量が 12 個の 3 ケ月流量のうち最大に なり，かつ年流量の概ね $40 \%$ を超える地域をそれぞ

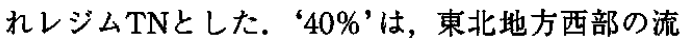
域がレジムTNに，東部の流域(レジムSに属するも のを除く)がレジムTPに属すように選んだ.よって 


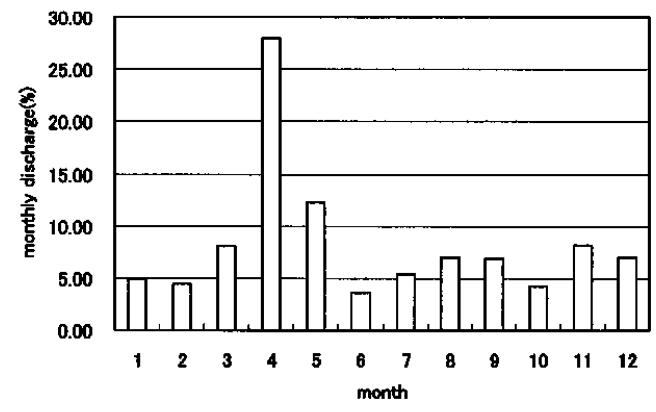

図ー4 平均月流量の年内变化(レジムTN)

Fig. 4 Monthly variability of discharge (Regime TN)

東北地方に限れば，レジムTNに属す流域は, 寺林 (北上川水系北上川)，広表(北上川水系和賀川)を除け ばすべて南北に走る暙梁山脈帯の西部に位置する.

図ー4に,レジムTNの例として, 上岩木橋(岩木川 水系岩木川)での月流量の年変化をあげる.

\section{3.レジムTP}

$3 ， 4 ， 5$ 月または $4,5 ， 6$ 月の 3 ヶ月流量が 12個の 3 ケ月流量のうち最大にはなるが, 夏期〜秋 期の流量も充分に大きい流域をレジムTPに属すと した.このレジムに属す流域の特徴は, 月流量に春 期・夏秋期，二度のピークが見られることである。 具体的には，TNと異なり，春期の 3 ヶ月流量が年 流量の $40 \%$ 未満になる場合とした. 図一 5 は，レジ 厶 TPに属す, 大曲橋(北上川水系北上川)での月流量 の年変化を示した図である.

のちに, 4 章以降で年最大流量の平均値, 変動係 数を用いた検討を行う際, レジムTN, TPは一括し て扱う。また，例えば夏秋期に抢いて 8，9，10月

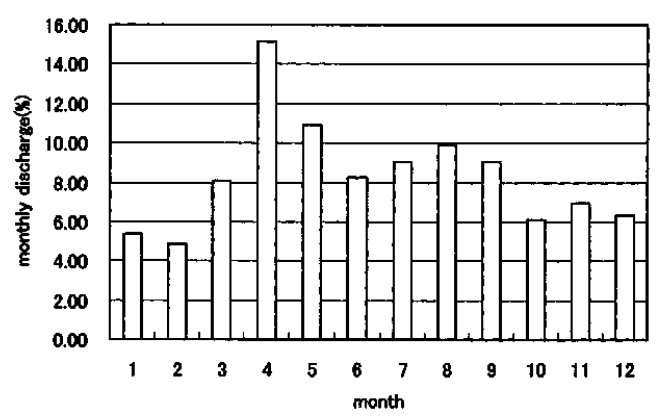

図一 5 平均月流旦の年内变化 (レジムTP)

Fig. 5 Monthly variability of discharge (Regime TP)
の 3 ヶ月流量が多い場合, レジムTP 9 等とするな ど，TPをさらに細分化した，あえて，TNとTPを 分けた理由，TPを細分化した理由はいずれも，少 雨の空間分析に関する解析を行う際に必要な情報に なり得る(葛菜ら，2001)からである.なお，例えば $4,5,6$ 月の 3 ケ月流量と $6,7,8$ 月の 3 ケ月 流量が多い場合, 双方に6月月月流量が含まれるの で, TP 7 とするのに問題があると考えたが，そう いう場合や，夏秋期に明らかな( 3 ケ月流量の)ピー クを持なない場合など, 細分化が困難な流域を, す ベてTP 7 に属すとした. ただし，貴志(紀の川水系 貴志川)，竜野(揖保川水系揖保川)については，4， 5,6 月の 3 ケ月流量が多いものの, それぞれ6月, 9 月が最大月流量を示す月であったため，TPには 入れず, 後述するSWに属すとした。

\section{4.レジムS}

春期以外に月流量が大きく，12月，1，2，3， $4 ， 5$ 月 (冬春期)の半年流量が年流量の $40 \%$ を超え ない流域をレジムSに属することとした.ここでも， 3 ヶ月流量が最大となる月により，S 7 等のように レジムの細分化を行った.

九州地方は気候区分としては瀬戸内, 北九州, 南 海に分割される(渡辺，1973)が，ほとんどの流域が レジムS 7 に属す. 図一6は中島(遠賀川水系彦山 川)に扔ける流量の年内変化を示した図であるが, このように九州地方の多くの流域では 7 月を中心に 左右対称に近い分布形状を示す．また，四国地方の 気候区分は瀬戸内と南海に分けられる，気候区分南 海に属す四国地方の流域の特徴として, 図一7の伊 野(仁淀川水系仁淀川)のように，9月に月流量の最 大值を示し，9月と10月に段差があることがあげら

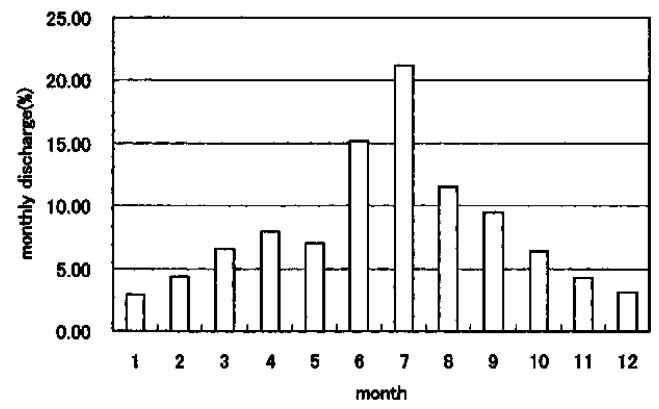

图一6 平均月流量の年内変化 (レジム S，中島) Fig. 6 Monthly variability of discharge (Regime S, at Nakashima) 


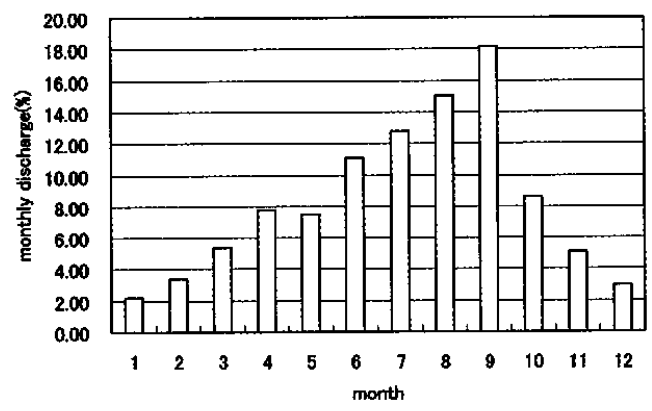

図一７平均月流異の年内变化(レジムS，伊野)

Fig. 7 Monthly variability of discharge (Regime $\mathrm{S}$, at Ino)

れる. その他の地方に関しても，6月等の夏の早い 時期に月流量の最大值を持つ地域と，9月を中心と した遅い夏期〜秋期に月流量の最大值を持つ地域が あるものの，もともと我が国ではこれらの季節に雨 期を迎える地域が多いので, 多くの流域がこのレジ ム S，または次で述べるレジムSWに属す。

\section{5.レジムSW}

春期以外に月流量が大きい地域の冬春期半年流量 は，多くの流域で，年流量の $30 \%$ 40\%程度になる， そこで, レジム S と類似であるが, 冬春期流量が年 流量の $40 \%$ を超える流域を, レジムSWに属するこ ととした。冬季にある程度の降雪があり, 春期に流 量が大きくなるが，春期 3 ケ月流量が極値をとらな い流域はここに含まれる，なお，本論文の 4 章以降 では，レジムS，SWを区別せずに検討を行う．そ れにもかかわらず,ここでレジム S, SWを分割し たのは, レジムTN, TPの場合と同じく, 少雨の空 間分布特性解析のためである. 図一8に,レジム

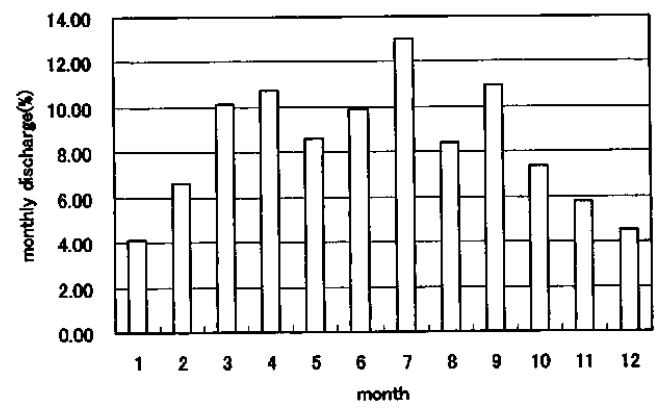

図一8 平均月流是の年内変化 (レジムSW)

Fig. 8 Monthly variability of discharge (Regime $\mathrm{SW})$
SWに属す, 桂(淀川水系桂川)での, 月流量の年内変 化を示す.

\section{6.レジムC}

流量の大小にかかわらず，月流量が年間をとおし てあまり変化しない流域をレジムCに属すとした。 図一 3 は西越(石狩川水系千歳川)の例である.

以上のように，対象河川流域を大きく分けて $6 \supset$ のレジムにクラス分けした．詳細については各レジ ムと流域名の対照表(表一1)を参照されたい.この 表で例えばレジムTPの欄に「保津峡(淀，桂，7)」 とあるのは,「淀川水系桂川の保津峡がTP 7 に属 す」ということを表している.

\section{CV-Area関係とSMAF-Area関係}

本章では, $\mathrm{CV} \cdot \mathrm{SMAF}$ 流域面積の関係の議論 に吕で求めたレジム分けを適用することを試みる. その目的は以下のと抒りである，すなわち，

1）で行ったレジム分けの妥当性を検証する. 比 流量に関する多くの研究(例えば角屋・永井, 1979)，建設省資料(建設省河川局治水課，1972)な どの例からも，レジム分けが適当であれば, SMAFが流域面積の増加に従って隇少する様子が (図一9よりより鮮明に)あらわれるはずである。

2）著者らは年最大流量と流域面積を用いた「降雨 一流出関係」の解析を行っている(葛葉ら，2000) が, 次のステップとして,レジムによるクラス分 けを導入した詳細な検討を行う.そこで,ここで は簡単な検討を行って, その可能性,つまりレジ ム分けを導入した「CV・SMAFと流域面積 (Area) の関係解析」の妥当性, 可能性を確認する. 図一 9の「CV一流域面積関係」は非常に複雑である が, 例えば, Blöschl and Sivapalan(1997)の理論 が正しく，その目的にあったレジム分けをしてい れば,「CVの流域面積に対する減少傾向」など，

レジム分けによってなんらかの特徴が見えてくる はずである.

まず，IIで述べたような方法で求めた「SMAFArea関係」と「CV-Area関係」を図一9に示す. 他国の流域を対象とした同様の図(例えばSmith, 1992 ; Blöschl and Sivapalan, 1997)と比較した場合, 1) SMAFは流域面積増加にともなって減少する傾 向がある.2) CVはあるthreshold(Smith(1992)， Blöschl and Sivapalan(1997)によると流域面積100k程 度.ここでは数 $100 \mathrm{~km}^{2}$ 程度)より流域面積が小さい場 

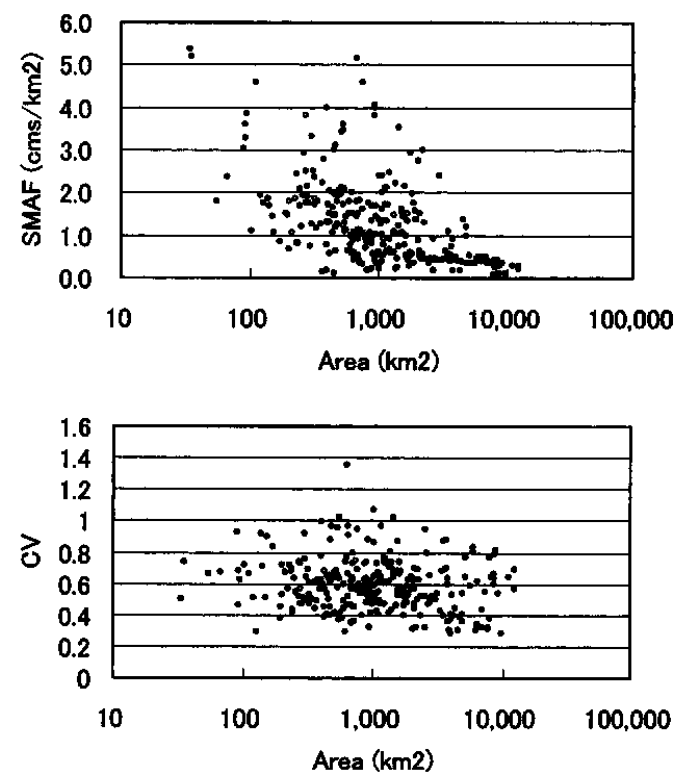

図一 9 SMAF-Area関係とCV-Area関係: 解析 対異流域全部

Fig. 9 Mean of maximum annual floods per unit area (specific mean annual floods; SMAF) and coefficient of variation (CV) for all available catchments in Japan plotted versus catchment area

合には増加傾向，それ以上では減少傾问があるなど， 類似の特徴を持った図となっている。しかし，例え ば「CV-Area曲線」によって「降雨一流出関係」 の関連を調べようとするなら，これらの図とも，そ の意味するところが不明確である。 そこで，ここに レジムの概念を導入し，解析を行うこととする.

そこでまず，融雪流出が卓越している流域を分離 することを試みる。图一10はレジムHに属す流域の みを対象とし，「SMAF-Area関係」と「CV-Area 関係」をプロットした図である．两図とも右下がり の傾向を持つことが見て取れるが，さらに明確な傾 向を見るために，レジムHのうち，石狩川水系に属 す流域と天塩川水系に属す流域に対する点に，それ ぞれ○とメを上書きした．水系ごとの傾向を見ると， よりいっそう面積に対してCV， SMAFが隇少する 様子がはっきりする. Eagleson(1972)，葛葉ら (2000)を参照すると，源流から下流まで降雨分布に 関するパラメータ, kinematic waveモデルに関す るパラメータが同じと仮定するなら，一つの水系に 属する流域のSMAFからなる「SMAF-Area曲線」
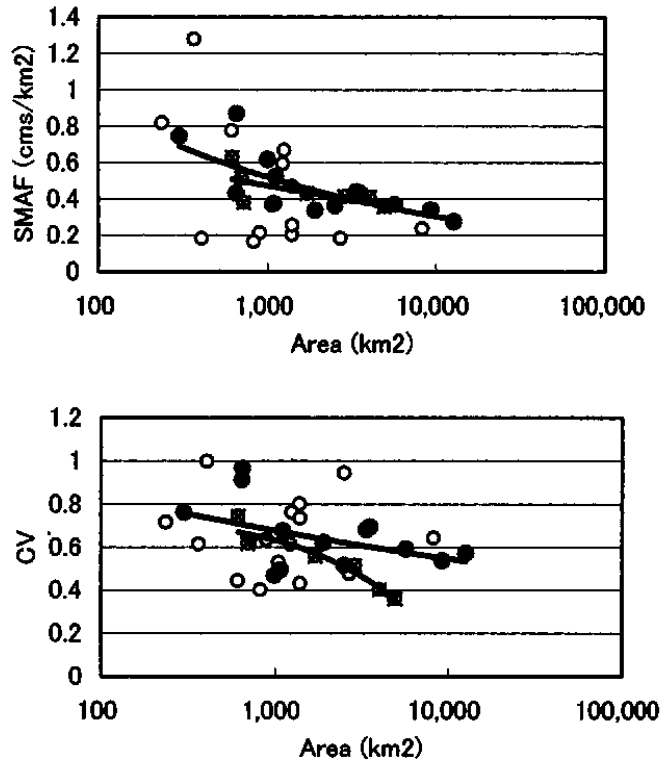

図一10 SMAF-Area関係 とCV-Area関係：レジ $\triangle \mathrm{H}$

Fig. 10 SMAF and CV plotted versus catchment area (Regime $\mathrm{H}$ )

は一本の曲線で表されるはずであるが，実際にはそ れらのパラメータが水系内で一定の值をとるわけで はない，すなわち流域がhomogeneousではないの で, 一本の曲線を描くことは希である。しかし, 石 狩川水系, 天塩川水系に関するそれぞれの関係を見 ることにより，レジムHの大まかな特徴をとらえる ことができる．四中にそれぞれの水系に対する近似 曲線を示したが, これらをプロットした点は水系ご とにほほ一つの曲線上にあるといえる．これらの石 狩川水系, 天塩川水系に対する曲線, また他の水系 に対する曲線の集合として，レジムHに対する図一 10が描けると考えられる.

つぎに, レジム $\mathrm{H}$ と同じく融雪流出が卓越してい ると考えられるレジムTNとTPを取り出してプロッ トした図を示す(図一11). 図中, ○で示した点は, レジムTN, TPのうち, 東北地方の流域に対する点 であり，図中に，近似曲線をひいた。これはTN, TPを一様に取り扱い，また図一10のように水系ご とのプロットを行ったものではないが, レジムHの 場合と同じく，この曲線はレジムTN, TPにおける， 「SMAF-Area関係」,「CV-Area関係」の特徴を表 しているものと考えられる、レジムTN，TPはレジ ム $\mathrm{H}$ と同じく春期に月最大流量を示す, 融雪流出が 

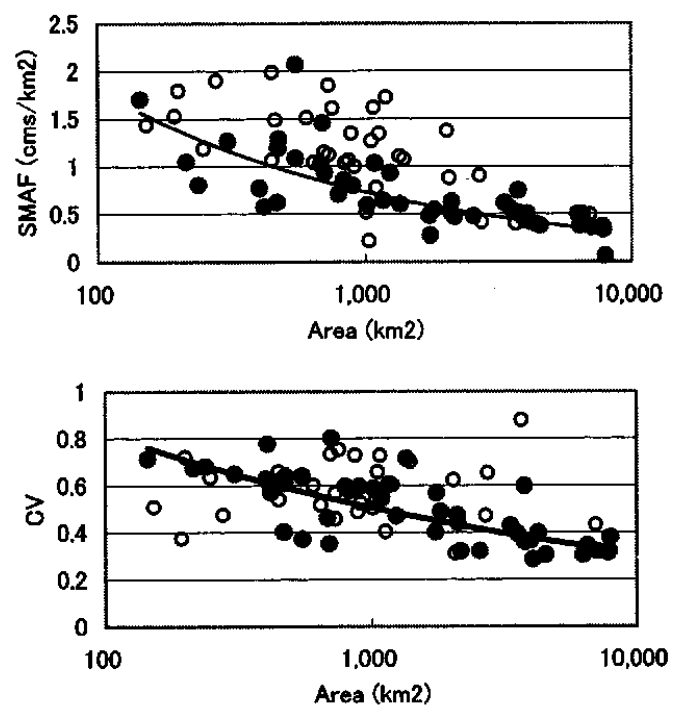

図一11 SMAF-Area関係 とCV-Area関係：レジ $\triangle T N, T P$

Fig. 11 SMAF and CV plotted versus catchment area (Regime TN and TP)

卓越するレジムであり，よって，その「SMAF-Area関係」「CV-Area関係」はレジムHのそれと類似

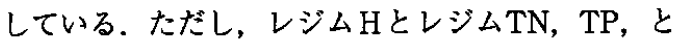
りわけ東北地方を対象とした図中の近似曲線を比較 すると, 後者の方が, よりCVが小さく, SMAFが 大きいこと，すなわち北海道の流域の方が(比流量 次元の)年最大流量が小さく，その変動が大きいこ とがわかる．また，レジムTN，TPの中では，東北 地方におけるSMAFが，特に流域面積 $1000 \mathrm{~km}^{2}$ 程度 の流域で比較的小さいことがわかる.

図一12は，レジムS，レジムSWに属す流域の 「SMAF-Area関係」,「CV-Area関係」をプロット したものである. 本研究で対象としている流域のう ち,レジムH, TN, TPを除いた他のほとんどの流 域はレジムS，SWに属すが，これらの流域は「春 期以外に月流量の最大値を示す」という特徴を持つ 流域で，それらは日本全国に存在するので，これら の関係図が複雑な形状を示すのは当然のことである.

ここで,レジムの概念に地域性を加えて，それら の関係を眺めてみる．図一13，图一14はそれぞれレ ジムS, SWに属す流域のうち, 我が国南西部に位 置する九州地方, 四国地方の流域での「SMAFArea関係」,「CV-Area関係」をプロットしたもの である.ここで, 図一13中, ○九州北中部(小出,
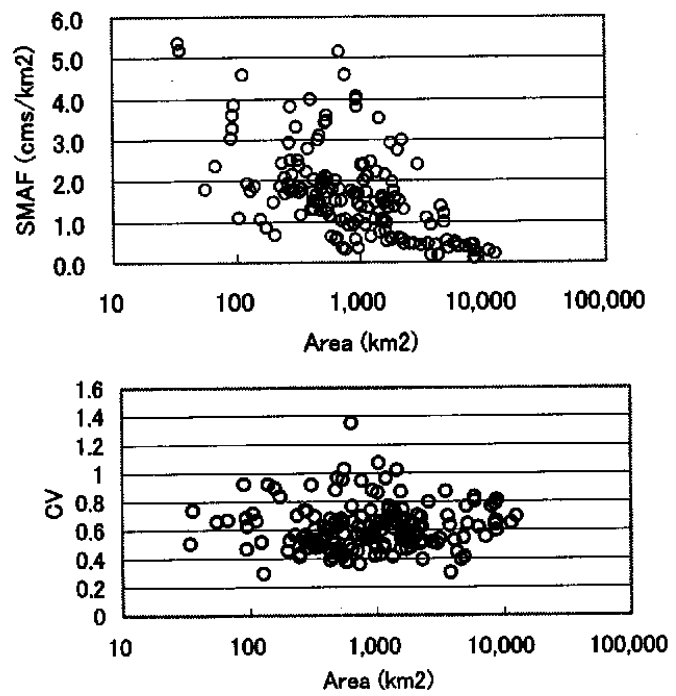

図ー12 SMAF-Area関係とCV-Area関係: レジ $\triangle \mathrm{S}, \mathrm{SW}$

Fig. 12 SMAF and $C V$ plotted versus catchment area (Regime S and SW)
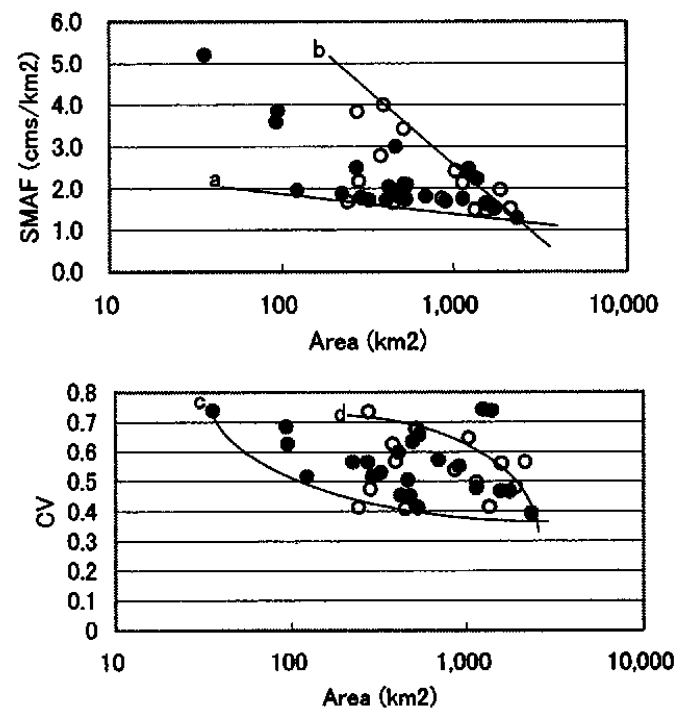

図-13 SMAF-Area関係 とCV-Area関係：レジ ムS，SWのうち九州地方

Fig. 13 SMAF and CV plotted versus catchment area (Regime $S$ and $S W$ in Kyushu region)

1970)の流域，○は南部の流域であることを示す. まず，「SMAF-Area関係」についてだが，九州北 中部，南部ともに, プロットされた点のほとんどが 

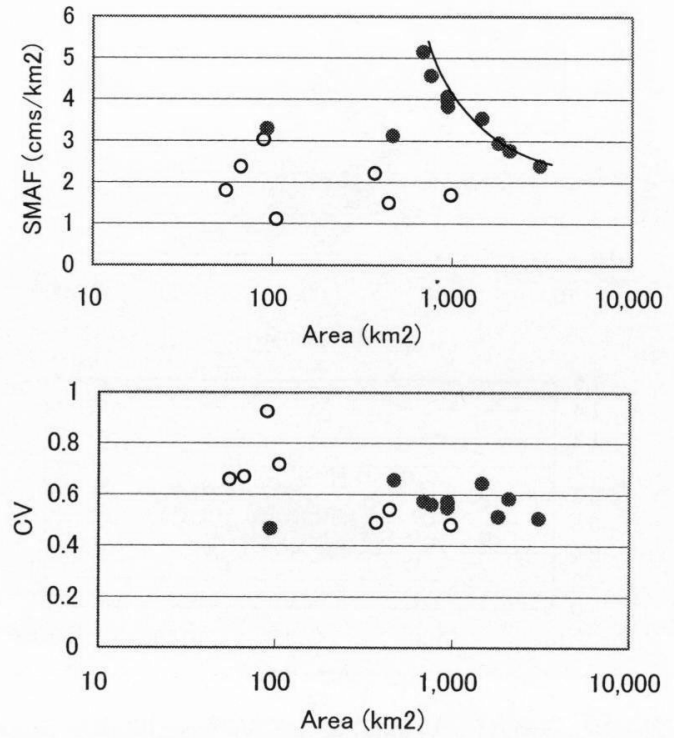

図ー14 SMAF-Area関係とCV-Area関係：レジ ム S, SWのうち四国地方

Fig. 14 SMAF and CV plotted versus catchment area (Regime S and SW in Shikoku region)

直線 $\mathrm{a}$, 直線 bの間に分布している。「SMAFArea関係」をあらわす明確な近似曲線は得られて いないものの, SMAFが流域面積の増加にともなっ て減少する傾向がはっきり見て取れる，CVに関し ても同様に, ほとんどの点が曲線 $\mathrm{c}$, 曲線 $\mathrm{d}$ の間に 広く分布しており, 同様に明確な近似曲線は得られ てはいないものの, 流域面積の増加にしたがって減 少する関係は見て取れる。なお，北海道のように同 一水系の河川流域だけを取り出してプロットしても 明確な近似曲線は得られなかった，正確な解析をす るためにはさらに詳しい他の情報が必要と考えるが, 以上のように，概ね流域面積増加に対する減少傾向 は表せたと考える。

四国地方については，CVの減少傾向は見て取れ るものの，SMAFに関してはばらつきが大きい。し かし，四国中南部の流域だけをとると(図中のの), 興味深いことがわかる。すなわち，二つの流域を除 いて，プロットした点が一本の曲線上に並ぶことで ある。これらの流域は同一水系に属しているわけで はなく, 渡川, 仁淀川, 那賀川, 吉野川水系に属し ている。これらの流域でのSMAFは，流域面積1000 $\mathrm{km}^{2}$ 程度で4.0〜 5.0 と，かなり大きな值を示してい る.
以上の九州・四国地方を除いた他のレジム S,

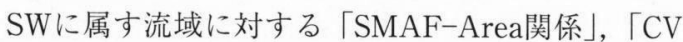
-Area関係」をプロットしたのが図ー15である。図 中， ○， $\triangle, \times$ はそれぞれ関東地方，中部地方，東 北·北陸地方の流域に対応し，○は近畿・中国地方 に対応している。まず「SMAF-Area関係」を眺め てみる。明らかに地方ごとに右下がりの曲線を描い ており，また中部地方の流域でSMAFが大きく，関 東地方及び東北・北陸地方で小さいことがわかる.

また，CVに関しては多少ばらつきは大きいもの の, 各地方とも, 若干右下がり, すなわち流域面積 の増大にしたがって減少する形状になっている．地 方ごとの違いを見ると，関東地方でCVが大きく，東 北・北陸地方，また中部地方で小さいことがわかる.

以上,レジムごとに,また, レジム S, SWでは, さらに地方ごとに細分類して「SMAF-Area関係」, $\lceil\mathrm{CV}-\mathrm{Area}$ 関係」を見てきた結果，以下のような ことがわかった. すなわち，

1）レジム H，TN，TPに関しては地方，また水系 ごとに細分化するとさらに傾向がはっきりするも のの，集合として見ても，SMAFの流域面積に対 する減少傾向はかなりはっきり現れている。 CV
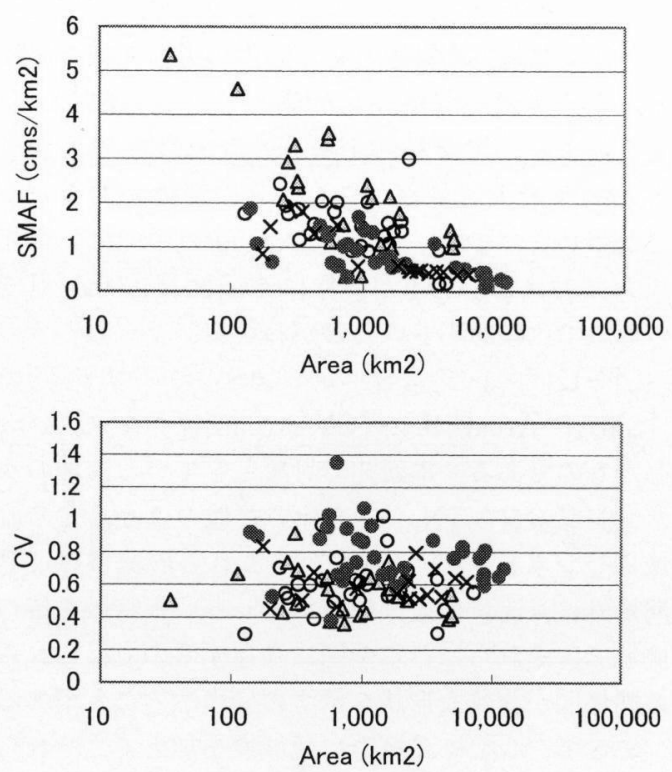

図-15 SMAF-Area関係とCV-Area関係：レジ ム S, SWのうち九州, 四国地方以外

Fig. 15 SMAF and CV plotted versus catchment area (Regime $\mathrm{S}$ and $\mathrm{SW}$ in regions except Kyushu and Shikoku) 
に関しても，SMAFほどではないが, 減少傾向が 見て取れる.すなわち, SMAFから判断して、レ ジム分けは妥当であり，またレジム分けを導入し た「CV·SMAFと流域面積の関係解析」の妥当 性, 可能性も示されたと考える.

2) レジムS, SWに関しては, 集合として見るな らCVの傾向が明暸ではないが, 地方ごとに細分 割するならその傾向がかなり明暸になる. SMAF から判断して,このレジムわけも一応の妥当性は 有していると考えるが,「レジム分けを導入した $\mathrm{CV} \cdot \mathrm{SMAF}$ 流域面積の関係解析の可能性」と いう観点からは, 本研究で行ったレジム分割に加 えて，地方ごとのさらなる情報により，この種の 解析が行えるという結果が示されたものと考える.

\section{V. 結 論}

流域年表のデータを用いて，日本の河川流域の分 類を試み, 結果として, 日本の河川流域を, 大きく 分けて 6 つのレジムに分けた. すなわち, レジム $\mathrm{H}$, $\mathrm{TN}, \mathrm{TP}, \mathrm{S}, \mathrm{SW}, \mathrm{C}$ である.さらに, レジムTP, $\mathrm{S}, \mathrm{SWに}$ 関しては，「どの3ヶ月流量が多いか」 を基準に細分化した。

つぎに，1）レジム分けの妥当性を検証するため， また，2）レジム分けによる「CV·SMAFと流域 面積 (Area)の関係」を介した降雨一流出過程の解析 の妥当性・可能性を検証するため,「SMAF-Area 関係」,「CV-Area関係」を調べた. 結果として, レジムH，TN，TPに関しては，1）の妥当性, 2) の妥当性・可能性が検証されたと考えるが，レ ジムS, SWに関しては, 地域性等, 追加情報があ る方が「降雨一流出過程の解析」がうまくゆくこと が示唆された。

また, 本研究では, いわば洪水災害に関係する年 最大流量を用いた検討を行ったが, レジム分類のも う一つの目的である, 渴水災害に関係する,「少雨 の時・空間分布特性」についても, 別に検討を行う (葛葉ら，2001）。

謝辞：有益な助言をいただいた西オーストラリア大 学のProf. Sivapalanに深謝致します.またデー夕整 理を手伝ってくれた防災科学技術研究所の草間香さ ん, 河野美佐江さんにも感謝する次第です.

\section{引用文献}

岩佐義朗(1979): 最新河川工学, p. 60 , 森北出版.
Blöschl, G. and Sivapalan, M. (1997) : Process controls on regional flood frequency: Coefficient of variation and basin scale, Water Resour. Res.. 33, pp. 2967-2980.

Creager, W.P. and Justin, J.D. (1944) : Engineering for Dams, 1, Wiley.

Eagleson, P.S. (1971) : The Stochastic kinematic wave, in Systems Approach to Hydrology, pp. 202-225, Water Resources Publications.

Eagleson, P.S. (1972) : Dynamics of flood frequency, Water Resour. Res., 8, pp. 878-898.

Gupta. V.K. and Dawdy, D.R. (1995) : Physical interpretations of regional variations in the scaling exponents of flood quantiles, Hydrolgical Processes, 9, pp. 347-361.

石原安雄・佐藤基(1975)：洪水比流量に関する研究, 京都大学防災研究所年報, $18, \mathrm{~B}$, pp. 415-423. 角屋睦・永井明博 (1979) : 洪水比流量曲線へのアプ ローチ, 京都大学防災研究所年報, $22, \mathrm{~B}-2$, pp. 195-208.

建設省土木研究所 (1976): 全国ダム地点地域別比流 量図(1975年)，土木研究所資料第1093号.

建設省河川局編：流量年表, 日本河川協会.

建設省河川局治水課 (1972) : 都道府県別中小河川, 小規模河川流域面積比流量図.

小出博(1970)：日本の河川一自然史と社会史一, 東 京大学出版会.

小出博(1972) : 日本の河川研究, 東京大学出版会.

Kresser, W. (1981): Die wasserwirtschaftlichen Verhältnisse in Österreich, in Schriften des Vereines zur Verbreitung naturwissenschafilicher Kenntnisse in Wien, pp. 69-97.

葛葉ら $(2000)$ : 平均年最大流量と流域スケール，水 工学論文集, 土木学会, 44, pp. 7-12.

葛葉ら (2001): 少雨の空間分布に関する研究, 水 文・水資源学会誌, 14(2), pp. 142-150.

日本農業土木総合研究所 (1984)：地域別河川比流量 の定量化に関する調查研究報告書.

Robinson, J.S. and Sivapalan, M. (1997) : An investigation into the physical cause of scaling and heterogeneity in regional flood frequency, Water Resour. Res., 33, pp. 1045-1059.

Smith, J.A. (1992) : Representation of basin scale in flood peak distributions, Water Resour. Res., 28, pp. 2993-2999.

渡辺 光(1973)：世界地理16 日本 I, pp. 61-66, 朝倉書店.

（受付：2000年 8 月 4 日，受理：2001年 1 月19日） 